\title{
Unit of Electric Charge Density
}

National Cancer Institute

\section{Source}

National Cancer Institute. Unit of Electric Charge Density. NCI Thesaurus. Code C68776.

A unit for measurement of electrical charge distribution over a line, surface, or volume. 